\title{
$\mathrm{LR}=$ INTERNATIONAL JOURNAL OF ACADEMIC \\ HUMAN RESOURCE
MARAEMENACADMMC
RESEARCH SOCIETY

\section{A Conceptual Paper Approach on the Effects of Psychological Contract Breach Among University Employees in Pakistan: Moderating Role of Perceived Organisational Support}

Rana Humayun Ihsan, Norizan Jaafar, Kartinah Ayupp, Bilyaminu Usman

To Link this Article: http://dx.doi.org/10.6007/IJARAFMS/v10-i3/7753

DOI:10.6007/IJARAFMS/v10-i3/7753

Received: 10 July 2020, Revised: 29 July 2020, Accepted: 25 August 2020

Published Online: 08 September 2020

In-Text Citation: (Ihsan, Jaafar, Ayupp, \& Usman, 2020)

To Cite this Article: Ihsan, R. H., Jaafar, N., Ayupp, K., \& Usman, B. (2020). A Conceptual Paper Approach on the Effects of Psychological Contract Breach Among University Employees in Pakistan: Moderating Role of Perceived Organisational Support. International Journal of Academic Research in Accounting, Finance and Management Sciences. 10(3), 150-159.

Copyright: (c) 2020 The Author(s)

Published by Human Resource Management Academic Research Society (www.hrmars.com)

This article is published under the Creative Commons Attribution (CC BY 4.0) license. Anyone may reproduce, distribute, translate and create derivative works of this article (for both commercial and non-commercial purposes), subject to full attribution to the original publication and authors. The full terms of this license may be seen at: http://creativecommons.org/licences/by/4.0/legalcode

Vol. 10, No. 3, 2020, Pg. 150 - 159

Full Terms \& Conditions of access and use can be found at http://hrmars.com/index.php/pages/detail/publication-ethics 


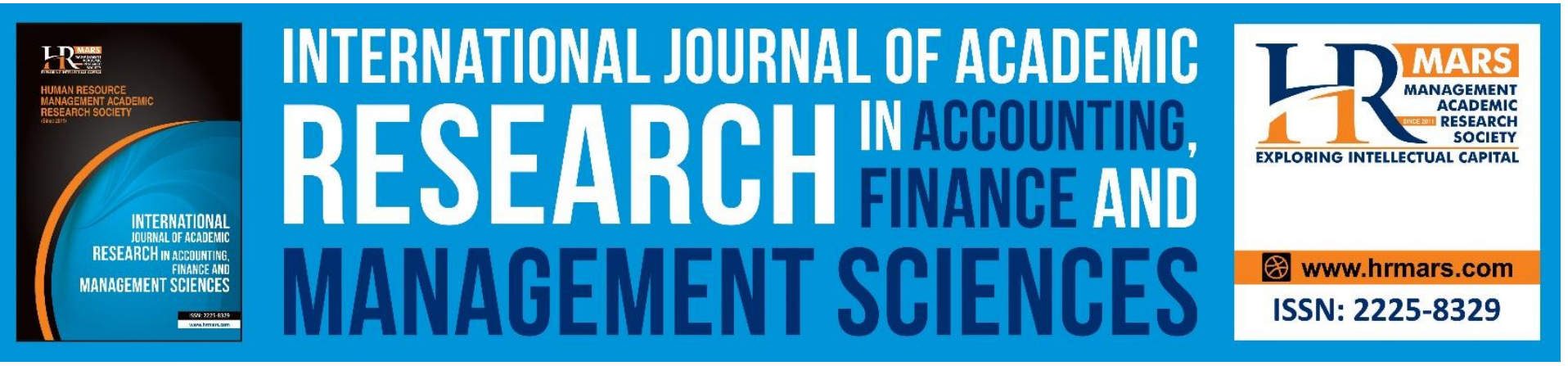

\title{
A Conceptual Paper Approach on the Effects of Psychological Contract Breach Among University Employees in Pakistan: Moderating Role of Perceived Organisational Support
}

\author{
Rana Humayun Ihsan, Dr. Norizan Jaafar, Dr. Kartinah Ayupp, \\ Bilyaminu Usman \\ PhD Researcher, Senior Lecturer, Associate Professor, PhD Researcher, Faculty of Economics and \\ Business, Universiti Malaysia Sarawak, Malaysia
}

\begin{abstract}
Psychological contract breach (PCB), which is an unwritten expectations-based contract between an employee and an employer, leads to negative attitudes and behaviours. PCB may be avoided by a number of ways. This paper argues that perceived organisational support (POS) may be used to mitigate the negative effects of PCB towards turnover intention (TI), job dissatisfaction (JS) and counterproductive work behaviours (CWB). This study proposes that PCB may be investigated using different samples so that results may be compared within and outside Pakistan. This paper is also presented as a proposed conceptual framework for future research based on theoretical triangulation from previous seminal studies in the international, the Asian and the Pakistani context. Keywords: Psychological Contract Breach, Job Satisfaction, Turnover Intention,
\end{abstract} Counterproductive Work Behaviour, Perceived Organisational Support.

\section{Introduction}

Employees are considered important asset for organisations (Apoi \& Latip, 2019). Organisations endeavour their best to fulfill employees' expectation and retain such a capital (Agarwal \& Bhargava, 2013). Psychologically fulfilled employees tend to be satisfied and productive (Lee, et al., 2011). Psychological contracts (PCs) are used to manage employees at the workplaces (Höglund, 2012). PCs are of two types i.e. relational and contractual (Rousseau, 2000). Psychological contract breach (PCB) is considered to be one of the reasons forcing employees to exhibit negative attitudes and behaviours such as job dissatisfaction (Shah, 2017), turnover intention (Adnan \& Khan, 2015) and counterproductive work behavior (Ahmed, Kiyani \& Hashmi, 2013).

Although a host of research studies have been conducted on PCB in Pakistan: PCB, turnover intention and job satisfaction (Ahmad \& Khan, 2015), PCB, work engagement and job satisfaction, (Saboor, Malik \& Pracha, 2017), PCB and political skills, work ethic, perceived politics and job attitudes 
INTERNATIONAL JOURNAL OF ACADEMIC RESEARCH IN ACCOUNTING, FINANCE AND MANAGEMENT SCIENCES

Vol. 10 , No. 3, 2020, E-ISSN: $2225-8329$ @ 2020 HRMARS

relationships (Khan, et al., 2018) and also outside Pakistan: PCB and work related outcomes (Zhao, et al., 2007), PCB and turnover intention (Chin \& Hung, 2013; Robinson, Kraatz \& Rousseau, 1994; Tekleab, Takeuchi, \& Taylor, 2005), PCB: counterproductive work behavior (Ma, et al., 2019), PCB and engagement, job satisfaction and organisational support (Westhuizen, Scheepers \& Kele, 2018), yet these studies were limited in terms of coverage and understanding of how psychological contract breach affects Pakistani workforce/workplaces and how perceived organisational support may moderate the relationships between psychological contract breach and job dissatisfaction, turnover intentions and counterproductive work behavior.

This conceptual paper discusses what PCB is all about, how it evolved over decades and what are its effects. Researchers have started taking PCs very importantly especially from the breach aspect in the Asian context (Agarwal \& Bhargava, 2013). This paper also discusses the empirical, methodological and theoretical gaps as well. PCs have mainly been studied by employing social exchange theory (Piccoli \& De Witte, 2015; Li \& Chen, 2018) and/or the norm of reciprocation (Karagonlar, Eisenberger \& Aselage, 2015). Little studies have used triangulation of social exchange theory (SET) and organisational support theory (OST). The former postulates that the employees return back what they get from their employers whereas the latter posits that employees return back well if they are given well. Overall, the studies on PCB have been conducted keeping in view its effects only (Agarwal \& Bhargava, 2013) that means other structural variable should be used to explore PCB more. Hence, keeping in view both the said theories, the conceptual framework shown in Figure. 1 proposes that perceived organisational support moderates the relationship between PCB and JS, TI and CWB.

\section{Literature and Hypothesis Development}

Psychological Contracts: A psychological contract means an unwritten agreement between an employee and an employer about the terms \& conditions of employment (Coyle-Shapiro \& Kessler, 2000). Argyris (1960) introduced the term psychological work contract whereby he advocated that employee-employer relationship is based on mutuality (Conway \& Briner, 2005). Rousseau (1989) said that PCs are used to study workplace ties. However, "a series of mutual expectations of which the parties to the relationship may not themselves be even dimly aware but which nonetheless govern their relationship to each other" were considered as psychological contract by Levinson, et al. (1962). Such contracts may be relational and/or transactional. There are three dimensions of these contracts i.e. psychological contract fulfilment, psychological contract violation and psychological contract breach.

Psychological Contract Breach: PCB is considered an organisational lapse regarding promises extended to employees (Rousseau, 1989). PCB leads to negative job attitudes and behaviours (Malik \& Khalid, 2016) and affects performance of employees (Hussain, Gul, Usman \& Islam, 2016). The negative attitudes and behaviours as outcomes of breach are many (Conway \& Briner, 2002; Raja, Johns \& Ntalianis, 2004; Zhao, et. al., 2007; (Bordia, Restubog \& Tang, 2008; Ahmad \& Khan, 2015). The breach aspect has wide range (Agarwal \& Bhargava, 2013) in the Asian context as well (Restubog, Bordia \& Robert, 2006). There is little exploration regarding psychological contract breach in the Asian context considering demographic factor (Ahmad \& Khan, 2015).

Job Satisfaction: The concept of job satisfaction was given due consideration by Maslow 
(1943), who introduced the needs hierarchy (theory). Job satisfaction has been defined as "a pleasurable or positive emotional state resulting from the appraisal of one's job or job experiences". Job dissatisfaction and turnover intentions are positively associated (Locke, 1976). Researchers believe that "a positive emotional and cognitive evaluation of their jobs is expected to push employees into being engaged with their jobs as reciprocation for the job satisfaction enabled by the organisation" (Rayton \& Yalabik, 2014). Job satisfaction, which is a very much important job attitude, which gets converted into dissatisfaction if employees experience PCB at the workplaces (Katou \& Budhwar, 2012). PCB leads to job dissatisfaction (Jamil, Raja, Darr, 2013).

Turnover Intentions: Turnover is a behavior and turnover intention (TI) is an attitude caused by job dissatisfaction (Locke, 1976). Tett and Meyer (1993) described turnover intention as an intentional attempt to get a new job outside one's organisation. Turnover intention has been associated with PCB (Chin \& Hung, 2013; Aykan, 2014). PCB causes turnover intentions and job dissatisfaction (Ahmad \& Khan, 2015; Turnley \& Feldman, 2000). Literature shows that turnover intention leads to actual turnover beaviour (Wang, Li, Wang \& Gao, 2017). Studies have revealed that turnover intention has a relationship with PCB (Ahmad \& Khan, 2015; Malik \& Khalid, 2016). Male and female employees take turnover intentions and turnover differently (Blomme, Van-Rheede, \& Tromp, 2010). One of the outcomes of PCB is turnover intention (Zhao, et al., 2007).

Counterproductive Work Behaviour: Chen and Spector (1992) held that counterproductive work behaviour (CWB) damages an organisation in four possible ways i.e. 'damaging the organisational-property', 'damaging the organisational-production', 'damaging the (senior and/or junior) colleagues by being aggressive', and 'damaging the organisational socio-political-image by disseminating fabricated-content about the organisation or its members'. CWB is the outcome of PCB (Malik \& Khalid, 2016; Zhao, et. al., 2007). CWB leads to huge losses to organisations (Latto, 2007; Matchulat, 2007). PCB has a positive association with CWB (Chao, Cheung, \& Wu, 2011). CWB is provoked by PCB (Griep, Vantilborgh \& Jones, 2018; Abela \& Debono, 2019).

Perceived organisational support (POS): Perceived organisational support (POS) means "an employee's perception that the organization values his or her work contributions and cares about the employee's well-being". Perceived organisational support leads to positive work attitudes and behaviour and thereby increases organisational performance (Eisenberger, Malone \& Presson, 2016). The more the organisational support the less employees get psychologically affected (Kurtessis, et al., 2015). Organisational understanding and support reduces PCB and increases employee engagement/retention (Rodwell \& Ellershaw, 2015). POS may moderate PCB and job attitudes and behaviours (Westhuizen, Scheepers \& Kele, 2018).

Organisations want high productivity and employee retention. Negative attitudes and behaviours damage productivity and cause huge losses to organisations, (Latto, 2007; Matchulat, 2007). A number of research attempts has explored PCB and CWB but this relationship needs further investigation in the Asian context (Chao et al., 2011) especially in Pakistan (Hussain,et. al., 2016). Literature shows that little has been investigated about PCB and job satisfaction in Pakistan (Ahmad \& Khan, 2015; Saboor \& Malik \& Pracha, 2017); PCB and TI (Ahmad \& Khan, 2015) and PCB and CWB (Ahmed, Kiyani \& Hashmi, 2013; Gulzar, et al., 2014).

Little is known about the relationship between PCB and demographics in Pakistan (Ahmad \& Khan, 2015). PCB has more been researched in the western countries (Zhao, et. al., 2007; Rayton \& Yalabik, 2014; Westhuizen, et al., 2018). Literature has suggested to investigate PCB more and in the 
Asian context as well (Agarwal \& Bhargava, 2013) especially in Pakistan (Hussain, et. al., 2016) as it would be unjustified to generalise western results in Pakistan (Bashir, 2011). Investigating PCB in Pakistan is justified as non-western research results have also been reported inconsistent with the western results (Lu, Siu, Spector \& Shi, 2009; Madipelli, Sarma \& Chinnappaiah, 2013).

Structural equation modelling (SEM) provides better analysis and path-understanding (Kline, 2005). A few studies has used SEM method to study PCB in relation to constructs of the present research together in relation to employees of the Pakistani universities. Besides, a few studies has used questionnaire method to research psychological contract of university administrative and teaching employees. Similarly, little is known about validation of the present study scales in Pakistan especially Pakistani universities. Therefore, this research aims to fill this gap by using SEM and a questionnaire based quantitative approach to study effects of $P C B$, its effects and moderating role of POS vis-a-vis the university employees in Pakistan.

A research model must be supported by some relevant theories (Hair, et al., 2010). Previous research depicts that researchers have employed theories such as expectancy theory, selfdetermination theory, attribution theory, social contract theory, uncertainty management theory, psychological ownership theory, conservation of resources theory, control theory, affective event theory, signaling, theory, social information theory, cognitive dissonance theory, psychological contract theory, perceived organisational support theory and agency theory in order to research psychological contract.

Psychological contract studies mainly rely on only social exchange theory. Therefore, other theories may also be used to research psychological contract (Kutaula, 2014). Nonetheless, literature shows that little studies have employed together the organisational support theory and the social exchange theory to researching PCB and other constructs of the present research. A number of studies/theories have been employed in countless studies from technological advanced countries, which comes to almost no more than one-third of the world-population. Generalization and application of such theories in the non-western cultural-context seems unjustified (Bashir, 2011). Therefore, this research is an attempt to employ the social exchange and the organisational support theories together in order to better understand psychological contract mechanism. Accordingly, this research aims to overcome this shortcoming by employing social exchange and organisational support theories together to study PCB and effects and moderating role of POS.

Study objectives and hypotheses are detailed below:

- To examine the effects of psychological contract breach among university employees in Pakistan.

- To examine the role between perceived organisational support and psychological contract breach and its negative attitudes and behaviours such as job dissatisfaction, turnover intention, counterproductive work behaviour and among employees in Pakistani universities.

- To examine if psychological contract breach affects demographic factors such as qualification, gender and age of employees in Pakistani universities? 
INTERNATIONAL JOURNAL OF ACADEMIC RESEARCH IN ACCOUNTING, FINANCE AND MANAGEMENT SCIENCES

Vol. 10, No. 3, 2020, E-ISSN: $2225-8329$ @ 2020 HRMARS

- $\mathrm{H} 1$ :

$\mathrm{H} 2$ :

H3:

H4:

H5: POS moderates

H6: POS

H7:

H8:

H9: PCB has association with gender. has

has

has

the

the

has

has moderates the

$\begin{array}{cccr}\begin{array}{c}\text { association } \\ \text { Association }\end{array} \text { with } & \text { JS. } \\ \text { association } & \text { with } & & \text { TI. } \\ \text { relationship between } & \text { PCB } & \text { and } & \text { JS. } \\ \text { relationship between } & \text { PCB } & \text { and } & \text { TI. } \\ \text { relationship between } & \text { PCB } & \text { and } & \text { CWB } \\ \text { association } & \text { with } & & \text { qualification. } \\ \text { association } & \text { with } & \text { age. }\end{array}$

association S.

TI.

WB.

TI.

\section{Proposed Conceptual Framework}

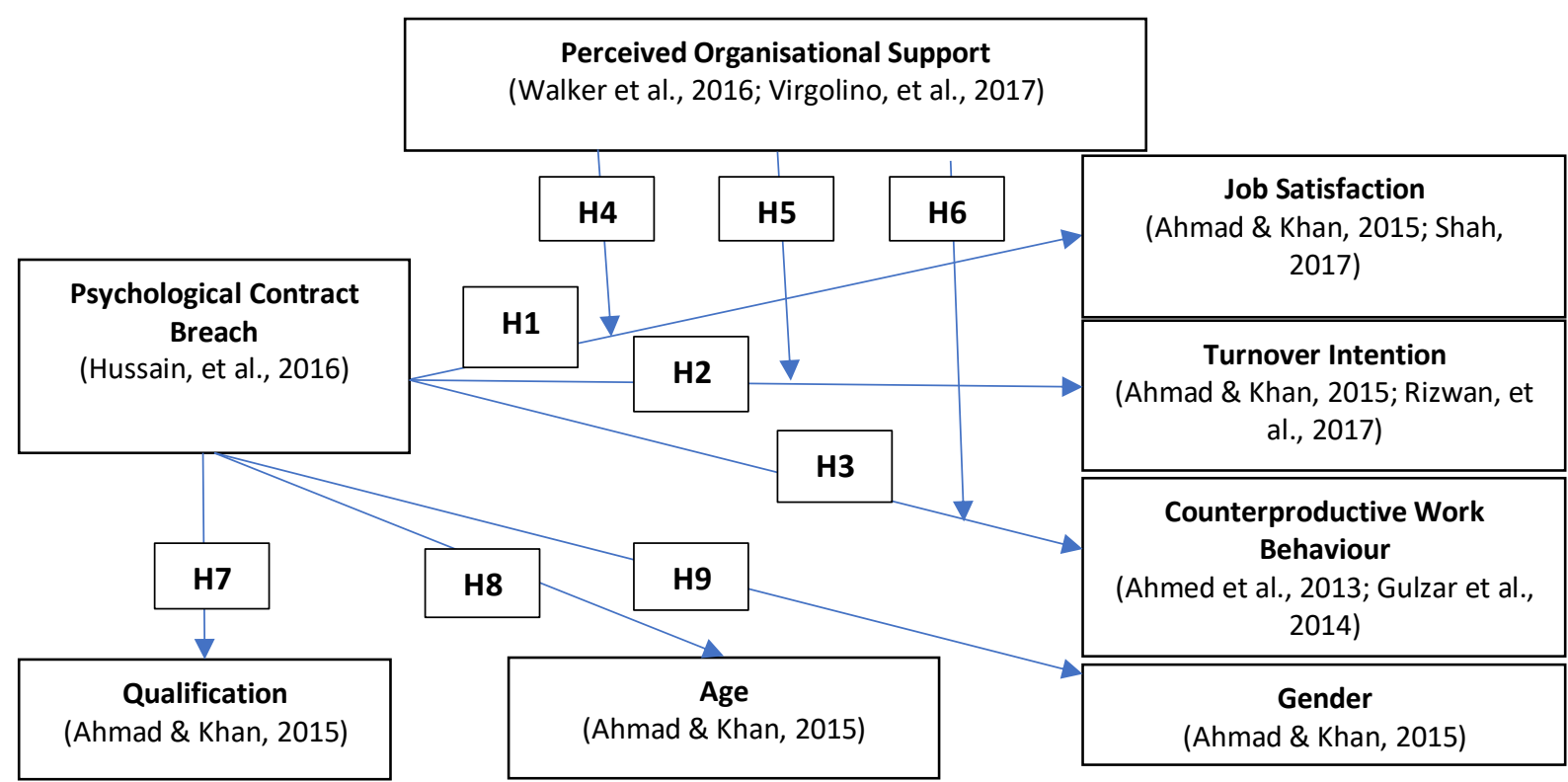

Figure 1: Proposed Conceptual Framework showing the Effects of Psychological Contract Breach Among University Employees in Pakistan

The proposed conceptual framework would help scholars, practitioners and organizations better understand the psychological contract mechanism with reference to its negative attitudes and effects and also the role of POS therein so that all concerned may contribute to the society by providing a psychologically conducive work environment.

\section{Discussion, Conclusion and Future Research Directions}

Empirical and conceptual studies have been conducted to examine PC and role of PCB regarding attitudes and behaviours of employees. These studies have held that PCB causes negative job attitudes and behaviours. Although PCB has widely been researched in the West yet research on PCB is limited in Pakistani workplaces especially with reference to PCB, JS, TI, CWB and POS.

PCB has been investigated mainly through quantitative research method; researchers may also carry out a longitudinal study and/or qualitative study to better understand this mechanism. The study at hand will prove to be an attempt to understand research on PCB by using a number of 
structural and contextual constructs as mediators and/or moderators concerning effective human resource management practices.

PCB leads to negative job outcomes i.e attitudes and behaviours. This breach is required to be mitigated/eradicated by truly understanding the PCB mechanism, which need deeper structural and contextual investigations especially in all sectors of Pakistan. Researchers and practitioners cannot be effective at employee management unless they fully understand the PCB mechanism and its effects on attitudes and behaviours of the employees. Therefore, the research scheme of this study may prove to be a better understanding of the PCB and attitudes and behaviours with a especial focus on Pakistani workplaces i.e. universities.

\section{References}

Abela, F., \& Debono, M. (2019). The relationship between psychological contract breach and jobrelated attitudes within a manufacturing plant. Sage Open, 9(1), 1-10.

Agarwal, U. A., \& Bhargava, S. (2013). Effects of psychological contract breach on organizational outcomes: Moderating role of tenure and educational levels. Vikalpa, 38(1), 13-25.

Ahmad, A., \& Khan, S. (2015). Psychological contract breaches and its impact on employee turn over intention and job satisfaction. European Journal of Business and Management, 7(10), 31-40.

Ahmed, W., Kiyani, A. A., \& Hashmi, S. H. (2013). The study on organizational cynicism, organizational injustice \& breach of psychological contract as the determinants of deviant work behavior. Actual Problems of Economics. Available at SSRN: https://ssrn.com/abstract=2743141

Apoi, A., \& Latip, H. B. A. (2019). The impact of transformational leadership on employee reactions towards individual work performance: A conceptual paper. International Journal of Academic Research in Business and Social Sciences, 9(8), 47-60.

Argyris, C. (1960). Understanding organizational behavior. Homewood: The Dorsey Press, Inc. USA.

Aykan, E. (2014). Effects of perceived psychological contract breach on turnover intention: Intermediary role of loneliness perception of employees. Procedia - Social and Behavioral Sciences, 150, 413-419.

Bashir, S. (2011). Organizational cynicism development and testing of an integrated model a study of public sector employees in Pakistan. Published PhD. Thesis. Muhammad Ali Jinnah University, Pakistan.

Blomme, R. J., van Rheede, A., \& Tromp, D. M. (2010). The use of the psychological contract to explain turnover intentions in the hospitality industry: A research study on the impact of gender on the turnover intentions of highly educated employees. The International Journal of Human Resource Management, 21(1), 144-162.

Bordia, P., Restubog, S. L. D., \& Tang, R. L. (2008). When employees strike back: investigating mediating mechanisms between psychological contract breach and workplace deviance. Journal of Applied Psychology, 93(5), 1104-1117.

Chao, J. M. C., Cheung, F. Y. L., \& Wu, A. M. S. (2011). Psychological contract breach and counterproductive workplace behaviors: Testing moderating effect of attribution style and power distance. The International Journal of Human Resource Management, 22(4), 763-777.

Chen, P. Y., \& Spector, P. E. (1992). Relationships of work stressors with aggression, withdrawal, theft and substance use: An exploratory study. Journal of Occupational and Organizational Psychology, 65(3), 177-184. 
INTERNATIONAL JOURNAL OF ACADEMIC RESEARCH IN ACCOUNTING, FINANCE AND

MANAGEMENT SCIENCES

Vol. 10 , No. 3, 2020, E-ISSN: $2225-8329$ @ 2020 HRMARS

Chin, P. L., \& Hung, M. L. (2013). Psychological contract breach and turnover intention: The moderating roles of adversity quotient and gender. Social Behavior and Personality, 41(5), 843859.

Conway, N., \& Briner, R. B. (2005). Understanding psychological contracts at work: A critical evaluation of theory and research. Oxford University Press. The UK.

Conway, N., \& Briner, R. B. (2002). A daily diary study of affective responses to psychological contract breach and exceeded promises. Journal of Organizational Behavior, 23, 287-302.

Coyle-Shapiro, J., \& Kessler, I. (2000). Consequences of the psychological contract for the employment relationship: A large scale survey. Journal of Management Studies, 37 (7)(903-930).

Eckerd, S., Boyer, K. K., Qi, Y., Eckerd, A., \& Hill, J. A. (2016). Supply chain psychological contract breach: An experimental study across national cultures. Journal of Supply Chain Management, 52(3), 1-15.

Eisenberger, R., Malone, G. P., \& Presson, W. D. (2016). Optimizing perceived organizational support to enhance employee engagement. SHRM-SIOP science of HR series. 1-22.

Griep, Y., Vantilborgh, T., \& Jones, S. K. (2018). The relationship between psychological contract breach and counterproductive work behavior in social enterprises: Do paid employees and volunteers differ? Economic and Industrial Democracy, 1-19.

Gulzar, S., Moon, M. A., Attiq, S., \& Azam, R. I. (2014). The darker side of high performance work systems: Examining employee psychological outcomes and counterproductive work behavior. Pakistan Journal of Commerce and Social Sciences, 8(3), 715-732.

Hair Jr, J. F., Black, W. C., Babin, B. J., \& Anderson, R. E., (2010). Multivariate data analysis (7th ed.). NY, USA: Pearson.

Höglund, M. (2012). Quid pro quo? Examining talent management through the lens of psychological contracts. Personnel Review, 41(2), 126-142.

Hussain, S., Gul, H., Usman, M., \& Islam, Z. U. (2016). Breach of psychological contract, task performance, workplace deviance: Evidence from academia in Khyber Pukhtunkhwa, Pakistan. CS Canada International Business and Management, 13(2), 12-20.

Jamil, A., Raja, U., \& Darr, W. (2013). Psychological contract types as moderator in the breachviolation and violation-burnout relationships. The Journal of Psychology, 147(5), 491-515.

Karagonlar, G., Eisenberger, R., \& Aselage, J. (2015). Reciprocation wary employees discount psychological contract fulfillment. Journal of Organizational Behavior, 37(1), 23-40.

Katou, A. A., \& Budhwar, P. S. (2012). The link between HR practices, psychological contract fulfillment, and organizational performance: The case of the Greek service sector. Thunderbird International Business Review, 54(6), 793-809.

Khan, H. S., Zhiqiang, M. A., Sadick, M. A., \& Musah, A. I. (2018). Investigating the role of psychological contract breach, political skill and work ethic on perceived politics and job attitudes relationships: A case of higher education in Pakistan. Sustainability, 10(2018), 1-21.

Kline, R. B. (2005). Principles and practice of structural equation modeling. The Guilford Press. New York, USA.

Kurtessis, J. N., Eisenberger, R., Ford, M. T., Buffardi, L. C., Stewart, K. A., \& Adis, C. S. (2015). Perceived organizational support: A meta-analytic evaluation of organizational support theory. Journal of Management, 43(6), 1854-1884.

Kutaula, S. (2014). Antecedents and outcomes of psychological contract fulfillment: An empirical 
INTERNATIONAL JOURNAL OF ACADEMIC RESEARCH IN ACCOUNTING, FINANCE AND

MANAGEMENT SCIENCES

Vol. 10 , No. 3, 2020, E-ISSN: $2225-8329$ @ 2020 HRMARS

study conducted in India. PhD Thesis. Cardiff University. The UK.

Latto, A. (2007). Managing risk from within: Monitoring employees the right way. Risk Management, 54(4), 30-34.

Lee, C., Liu, J., Rousseau, D. M., Hui, C., \& Chen, Z. X. (2011). Inducements, contributions, and fulfillment in new employee psychological contracts. Human Resource Management, 50(2), 201-226.

Levinson, H., Price, C. R., Munden, K. J., Mandl, H. J., \& Solley, C. M. (1962). Men, management, and mental health. Harvard University Press, USA.

Li, S., \& Chen, Y. (2018). The relationship between psychological contract breach and employees' counterproductive work behaviors: The mediating effect of organizational cynicism and work alienation. Frontiers in Psychology, 9(July), 1-13.

Locke, E. (1976). The nature and causes of job satisfaction. In: Dunnette, M.D. (Ed.), Handbook of Industrial and Organizational Psychology. Chicago: Rand-Mcnally.

Lu, J. F., Siu, O. L., Spector, P. E., \& Shi, K. (2009). Antecedents and outcomes of a fourfold taxonomy of work-family balance in Chinese employed parents. Journal of Occupational Health Psychology, 14(2), 182-192.

Ma, B., Liu, S., Lassleben, H., \& Ma, G. (2019). The relationships between job insecurity, psychological contract breach and counterproductive workplace behavior. Personnel Review , 48(2), 595-610.

Madipelli, S., Sarma, V. S. V., \& Chinnappaiah, Y. (2013). Factors causing work life imbalance among working women-a study on school teachers. Indian Journal of Industrial Relations, 48(4), 621634.

Malik, S. Z., \& Khalid, N. (2016). Psychological contract breach, work engagement and turnover intention: evidence from banking industry in Pakistan. Pakistan Economic and Social Review, 54(1), 37-54.

Matchulat, J. J. (2007). Separating fact from fiction about workplace violence. Employee Relations Law Journal, 1-13.

Piccoli, B., \& De Witte, H. (2015). Job insecurity and emotional exhaustion: Testing psychological contract breach versus distributive injustice as indicators of lack of reciprocity. Work \& Stress, 29(3), 246-263.

Raja, U., Johns, G., \& Ntalianis. (2004). The impact of personality on psychological contracts. Academy of Management Journal, 47(3), 350-367.

Rayton, B. A., \& Yalabik, Z. Y. (2014). Work engagement, psychological contract breach and job satisfaction. The International Journal of Human Resource Management, 25(17), 2382-2400.

Restubog, S. L. D., Bordia, P., \& Tang, R. L. (2006). Effects of psychological contract breach on performance of IT employees: The mediating role of affective commitment. Journal of Occupational and Organizational Psychology, 79(2), 299-306.

Robinson, S. L., Kraatz, M. S., \& Rousseau, D. M. (1994). Changing obligations and the psychological contract: A longitudinal study. Academy of Management Journal, 37(1), 137- 152.

Rodwell, J., \& Ellershaw, J. (2015). What is exchanged in psychological contracts? Multiple sets of obligations, targeted effort and uncertainty reduction. Employee Relations, 37(2), 232-247.

Rousseau, D. M. (1989). Psychological and implicit contracts in organizations. Employee Responsibilities and Rights Journal, 2, 121-139.

Rousseau, D. M. (2000). Psychological Contract Inventory: Technical Report (Vol. 3), 1-53. Pittsburgh, 
Pennsylvania 15213 USA.

Saboor, M. J., Malik, S., Pracha, A. T., Ahmed, W. S., \& Malik, T. (2017). Effect of psychological contract breach and job satisfaction on work engagement; $A$ case of higher education institute of Pakistan. Journal of Managerial Sciences, 11(3), 279-296.

Shah, A. B. (2017). An empirical analysis of the determinants to the employee job satisfaction In private corporate sectors of Pakistan. Biannual Research Journal Grassroots, 50(3), 53-66.

Tekleab, A. G., \& Taylor, M. S. (2003). Aren't there two parties in an employment relationship ? Antecedents and consequences of organization-employee agreement on contract obligations and violations. Journal of Organizational Behavior, 24(2003), 585-608.

Tekleab, A. G., Takeuchi, R., \& Taylor, M. S. (2005). Extending the chain of relationships among organization justice, social exchange, and employee reactoins: The role of contract violations. Academy of Management Journal, 48(1), 146-157.

Tett, R. P., \& Meyer, J. P. (1993). Job satisfaction, organizational commitment, turnover intention, and turnover: path analyses based on meta- analytic findings. Personnel Psychology, 46(2), 259293.

Turnley, W. H., \& Feldman, D. C. (2000). Re-examining the effects of psychological contract violations: Unmet expectations and job. Journal of Organizational Behavior, 21(1), 25-42.

Virgolino, A. I., Coelho, A., \& Ribeiro, N. (2017). The impact of perceived organizational justice, psychological contract and the burnout on employee performance: The moderating role of organizational support, in the Portuguese Context. International Journal of Academic Research in Business and Social Sciences, 7(1), 241-263.

Walker, A., Accadia, R., \& Costa, B. M. (2016). Volunteer retention: The importance of organisational support and psychological contract breach. Journal of Community Psychology, 44(8), 1059-1069.

Wang, Y., Li, Z., Wang, Y., \& Gao, F. (2017). Psychological contract and turnover intention: The mediating role of organizational commitment. Journal of Human Resource and Sustainability Studies, 5(1), 21-35.

Westhuizen, T. V. D., Scheepers, C. B., \& Kele, T. (2018). The relationship between psychological contract breach and engagement: Job satisfaction and organisational support as moderators. Journal of Economics and Behavioral Studies, 10(3), 187-202.

Zhao, H. A. O., Wayne, S. J., Glibkowski, B. C., \& Bravo, J. (2007). The impact of psychological contract breach on work-related outcomes: A meta-analysis. Personnel Psychology, 60(3), 647-680. 